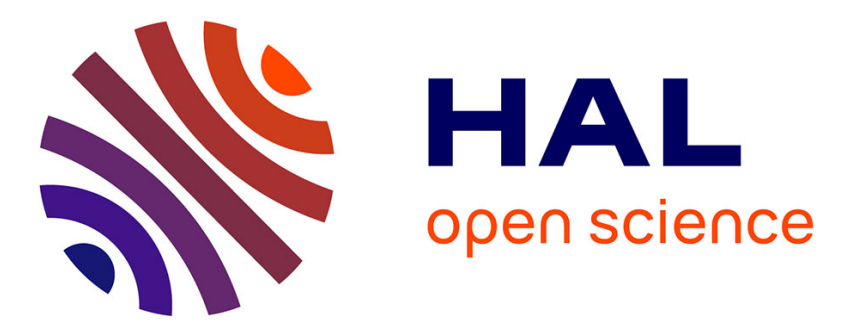

\title{
The safety and efficacy of an injectable bone substitute in dental sockets demonstrated in a human clinical trial.
}

Pierre Weiss, Pierre Layrolle, Léon Philippe Clergeau, Bénédicte Enckel, Paul Pilet, Yves Amouriq, Guy Daculsi, Bernard Giumelli

\section{- To cite this version:}

Pierre Weiss, Pierre Layrolle, Léon Philippe Clergeau, Bénédicte Enckel, Paul Pilet, et al.. The safety and efficacy of an injectable bone substitute in dental sockets demonstrated in a human clinical trial.. Biomaterials, 2007, 28 (22), pp.3295-305. 10.1016/j.biomaterials.2007.04.006 . inserm-00166069

\section{HAL Id: inserm-00166069 https://www.hal.inserm.fr/inserm-00166069}

Submitted on 27 Sep 2007

HAL is a multi-disciplinary open access archive for the deposit and dissemination of scientific research documents, whether they are published or not. The documents may come from teaching and research institutions in France or abroad, or from public or private research centers.
L'archive ouverte pluridisciplinaire HAL, est destinée au dépôt et à la diffusion de documents scientifiques de niveau recherche, publiés ou non, émanant des établissements d'enseignement et de recherche français ou étrangers, des laboratoires publics ou privés. 
Figure 1: Radiographic pictures of ICPCS-filled mesial socket of a first molar from day of injection to 6 months. ICPCS was composed of MBCPTM ceramic granules 80-200 $\mu \mathrm{m}$ suspended in $2 \%$ cellulose saline solution. Notice the progressive disappearance of the radioclear line outlining the defect and the increase in radiographic density with time.

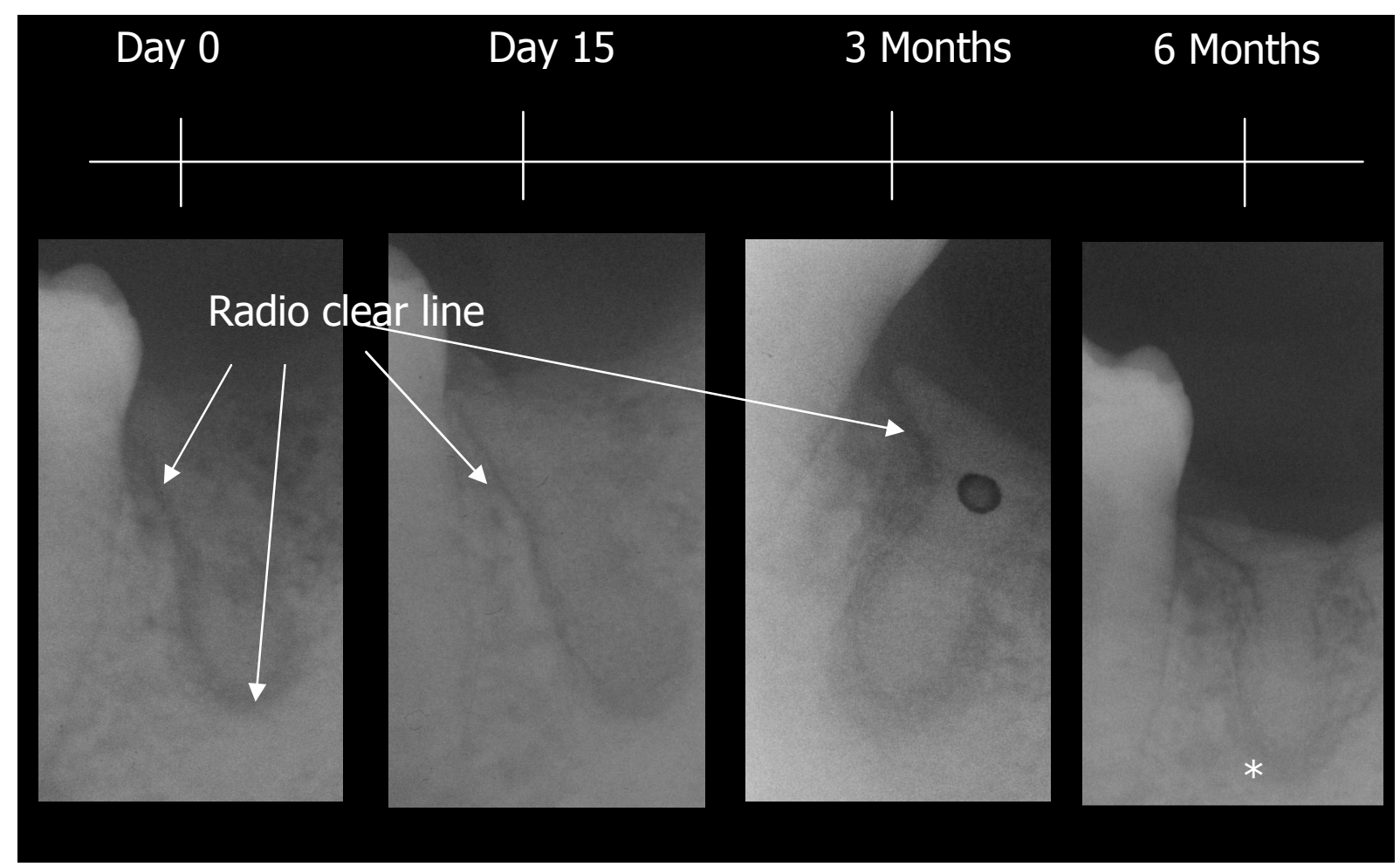


Figure 2: Relative radiographic density measured of the ICPCS-filled dental sockets $(n=18)$ as a function of implantation time.

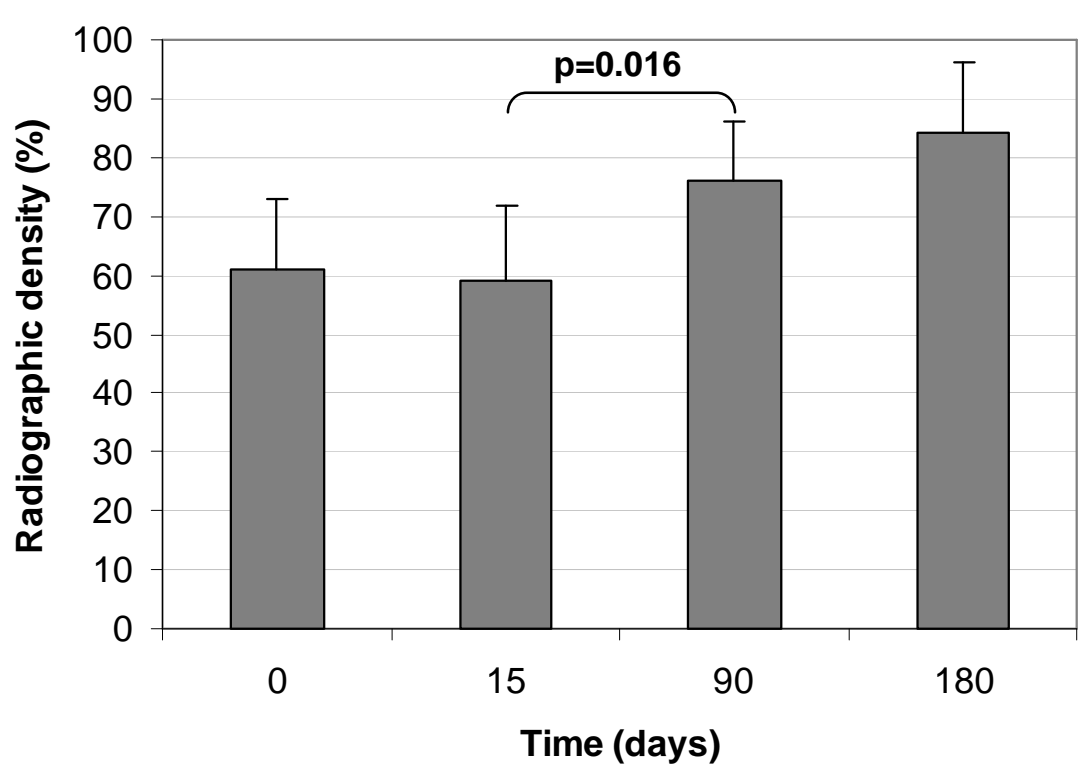


Figure 3: Radiographic of dental socket 6 months and 3 years after tooth extraction and filling with ICPCS. Notice the fading of the initial defect and the increase in mineral density over time.

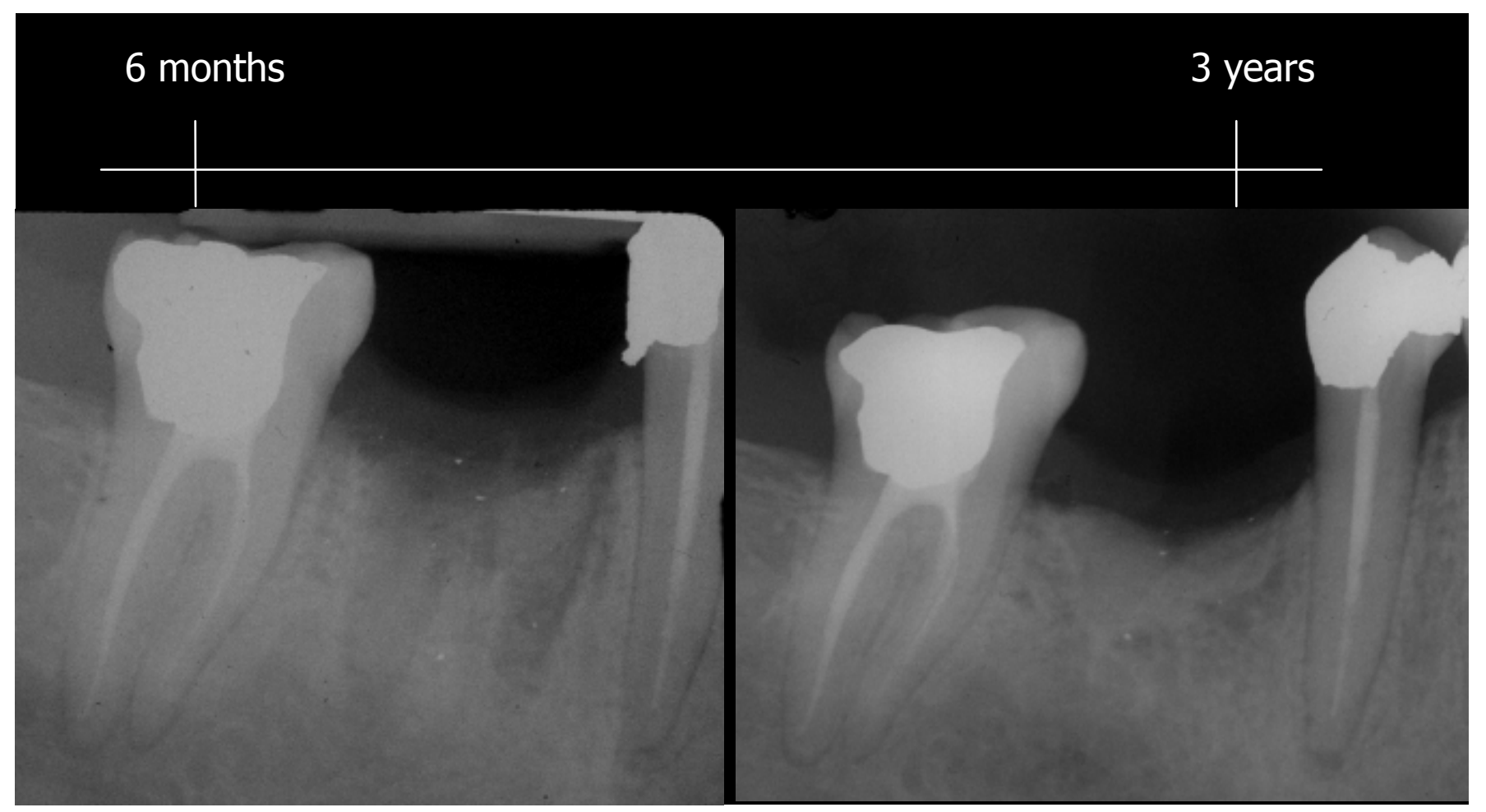


Figure 4: Clinical picture of the opened implanted area 3 years after filling the dental socket with ICPCS and just prior to harvesting the biopsy. This picture corresponds to the radiography shown in Figure 3 (Case 1).

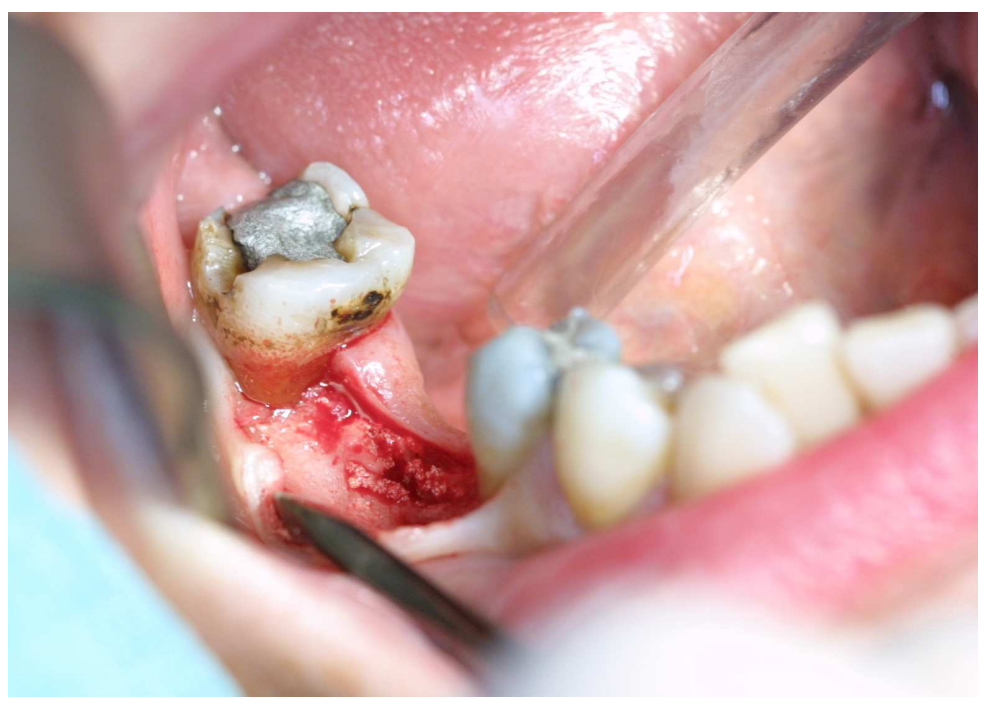


Figure 5: Histological analysis of the biopsy harvested 3 years after filling the dental socket with ICPCS (case 1). (a) SEM micrograph showing the BCP granules 80-200 $\mu \mathrm{m}$ and mineralized bone $(*)$ in the lowest region of the defect, (b, c and d) histological sections showing osteoid tissue between the ceramic granules (Movat's pentachrome and Goldner's trichrome staining).

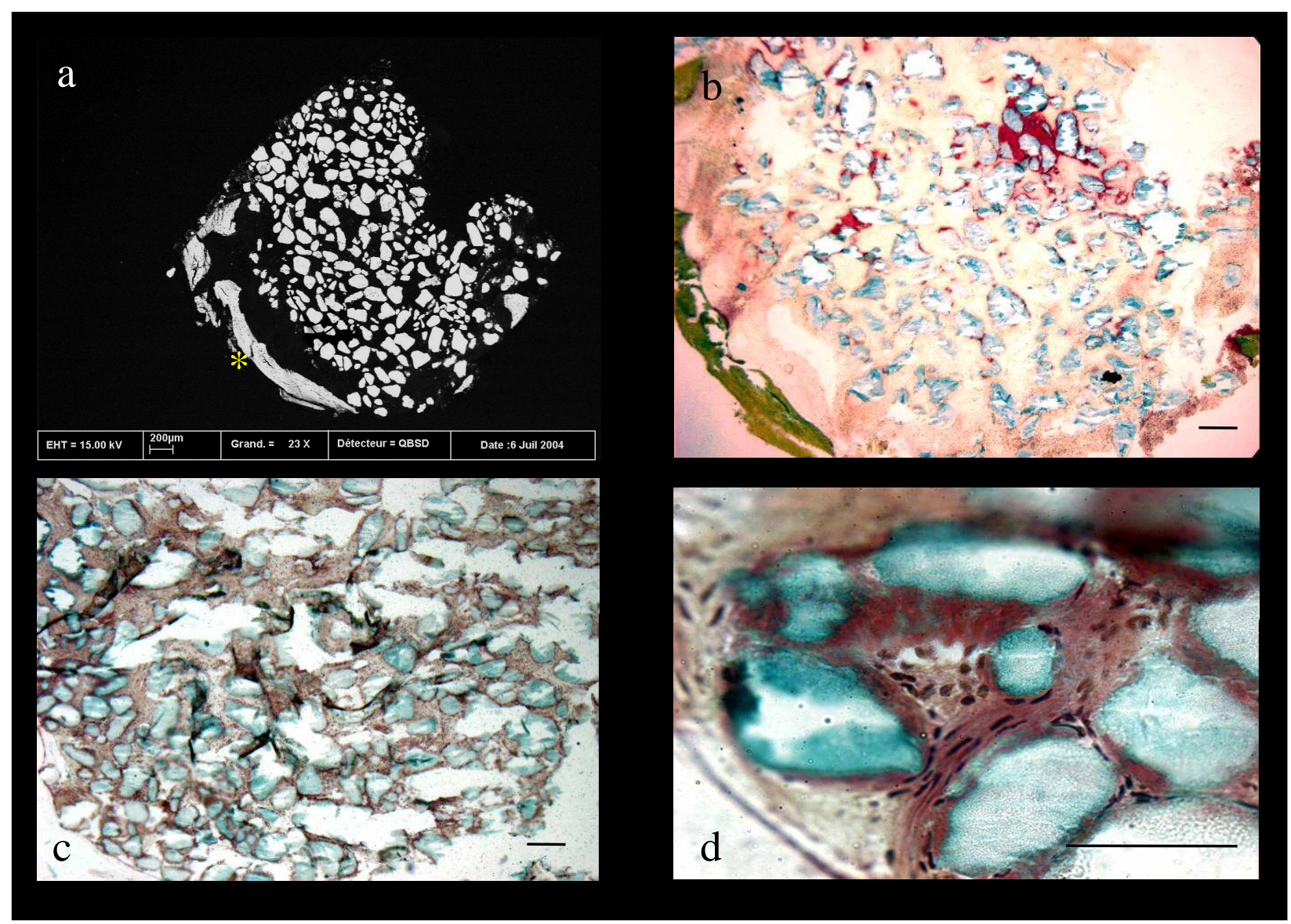


Figure 6: Analysis of the biopsy harvested 3 years after filling the dental socket with ICPCS (case 2). (a, b) SEM micrographs exhibiting mineralized bone in contact with the ceramic granules, (c) micro-tomography 3D picture and (d) histology thin section showing osteoid and mineralized bone tissue between the granules (Goldner's trichrome stain).

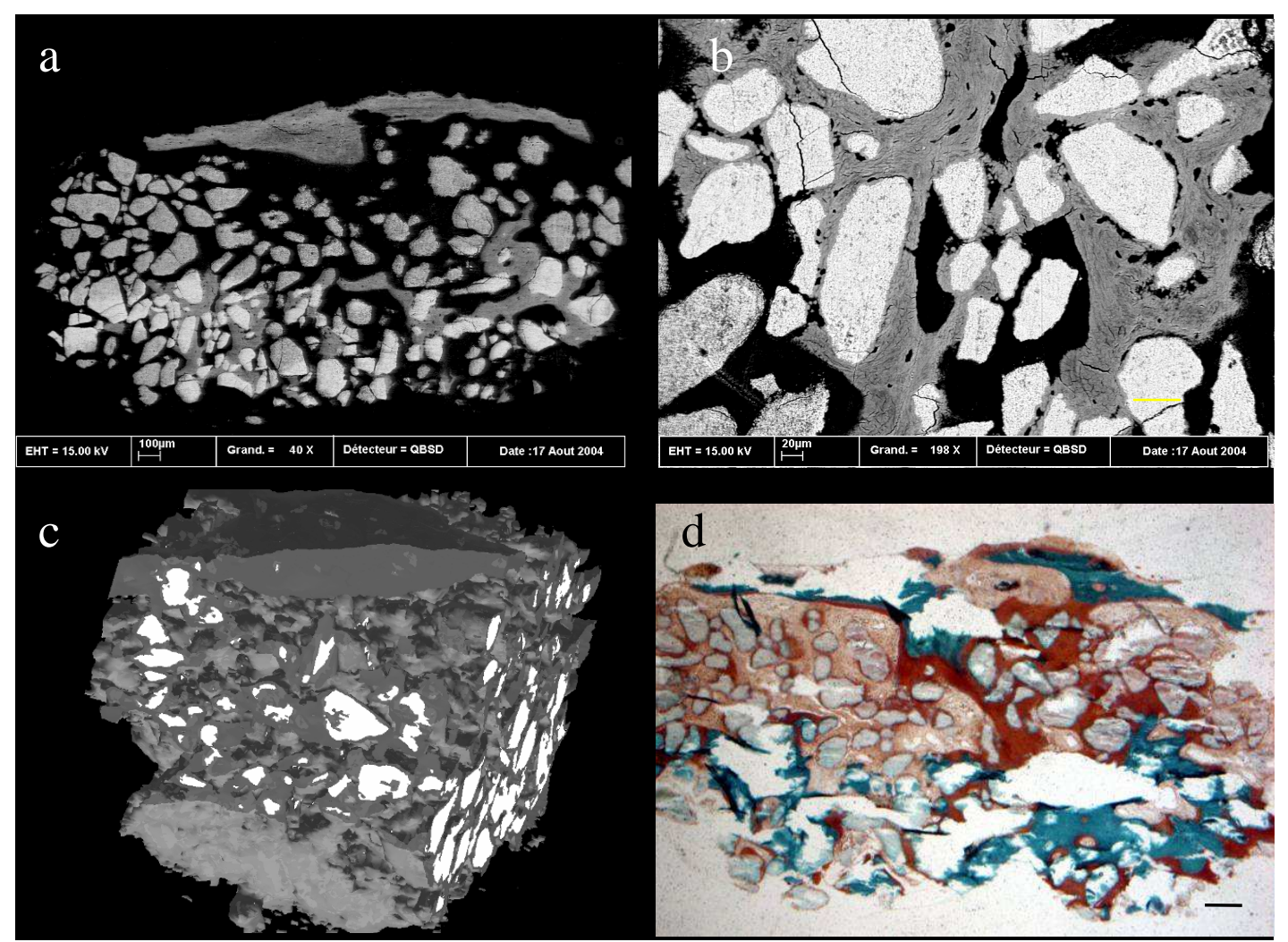


Figure 7: TEM micrographs of the biopsy harvested 3 years after filling the dental socket with ICPCS (case 2). (a,b,c) : Upper soft tissue region of the biopsy, just under the gum. (d,e,f) : lowest region of the biopsy.
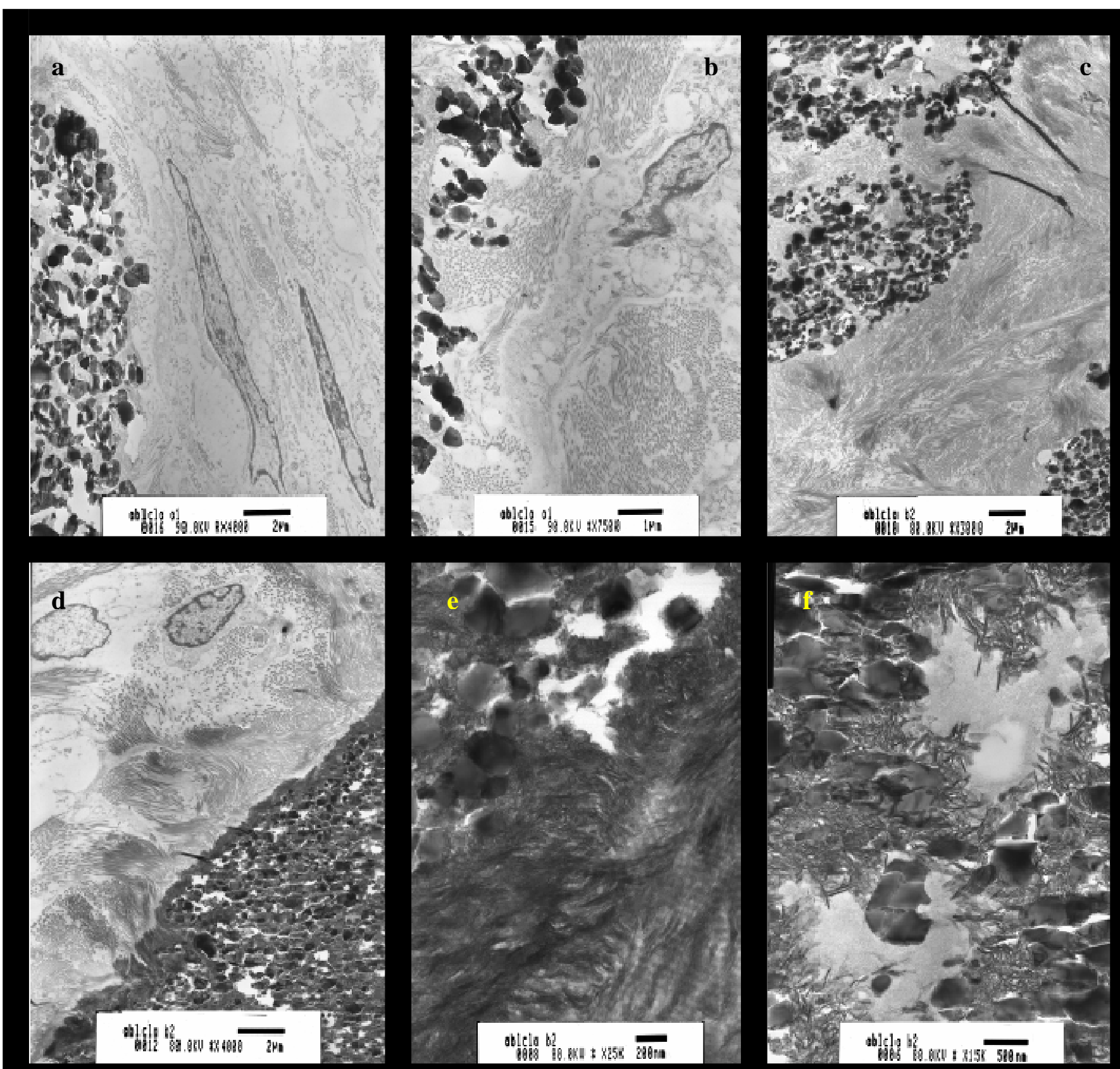
Figure 8: Analysis of the biopsy harvested 3 years after filling the dental socket with ICPCS (case 3). (a) SEM micrographs exhibiting abundant mineralized bone in contact with few ceramic granules, (b) micro-tomography 3D picture showing 3D bone growth, (c) polirized light microcopy picture with orientated minerlized collagen fibers and (d) histology thin section showing abundant mineralized bone tissue and some osteoid tissue (Goldner's trichrome stain).

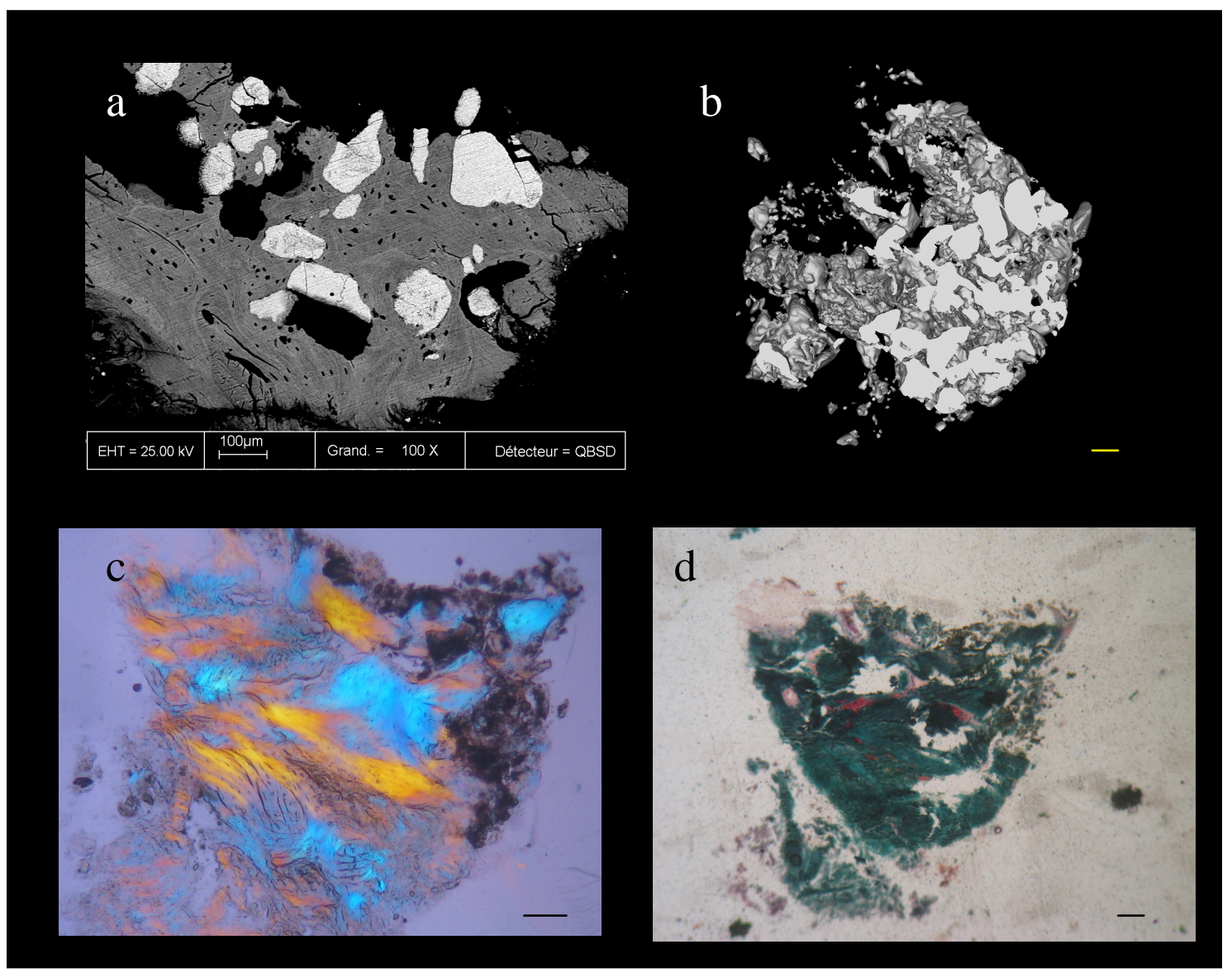

